\title{
A gyermekkel rendelkező és a nem gyermekes férfi dolgozók karrier elképzelései
}

\author{
DR. JUHÁSZ TÍMEA ${ }^{1}$ - KÁLMÁN BOTOND² - DR. TÓTH ARNOLD ${ }^{3}$
}

\section{ABSZTRAKT}

A munka és család összehangolása fokozottabb figyelmet kap a társadalomtudományi kutatásokban. Sokáig a vizsgálatok elsôsorban a kisgyermekes nők helyzetével foglalkoztak, ám későbbiekben a kutatók hamar felfigyeltek arra a tényre, hogy nemcsak a nőknek, de a férfiaknak is gondot okoz e két terület összehangolása.

Mint ahogy Bencsik-Juhász (2012) írja: „Miután a tényleges munkapiacon a férfiak foglalkoztatása a meghatározóbb és elfogadottabb, az ezzel járó minden előnnyel (például magasabb bérezés azonos munkakörökben) és hátránnyal (például hosszabb munkaidő), nem véletlen tehát, hogy a nők egyre erőteljesebb munkaerő-piaci jelenlétével és aktivitásával a hagyományos családi szerepmegosztások is lassan formálódnak és átalakulnak" (Bencsik - Juhász 2012: 616).

A közvélemény lassan két elvárás-rendszert tekint a férfiakkal szemben: még mindig tartósan, és erôsen él a köztudatban a hagyományos családfenntartó szerep, miközben részt vár a férfiaktól a gyermeknevelésben is. Kérdés, hogy ezek a folyamatok hatással vannak-e a férfiak karrierterveire?

A tanulmány a gyermekkel rendelkező és a gyermekkel nem rendelkező férfi dolgozók karrier elképzeléseit mutatja be. A szerzők egy kvantitativ felmérést készítették a kérdés megismerésére. A 2016-os kutatás alapján elmondható, hogy e két csoportba tartozó férfiak különböznek a kérdést illetően.

KULCSSZAVAK: a gyermekkel rendelkező és a gyermekkel nem rendelkező férfi dolgozók, karrier, munka és magánélet összeegyeztetése, nemi szerep, konfliktus

\section{ABSTRACT}

\section{The Career Concepts of Male Workers with or without Child}

The question of reconciliation of work and family is getting highlighted in social studies. For a long time, a lot of studies concentrated on young mothers; however, researchers have realized that this problem proves difficult to men as well. As Bencsik-Juhász write: "As the actual labor market primarily employs and caters for men, with all the inherent ad-vantages (like higher

\footnotetext{
${ }^{1}$ PhD, SAP tanácsadó.

${ }^{2}$ Jogász (osztatlan) hallgató, Eötvös Lóránd Tudományegyetem, Állam- és Jogtudományi Kar.

${ }^{3} \mathrm{PhD}$, főiskolai docens, Budapesti Gazdasági Egyetem.
} 


\section{TEMATIKUS TANULMÁNYOK - Menedzsment: vezetők, vezetés és munkavállalók}

wages for the same job) and disadvantages (like longer working hours), it is no wonder that the stronger labor-market presence and activity of women also changes the traditional family roles"(Bencsik - Juhász 2012: 616). The public opinion has been starting to expect double sets of obligations from the fathers, the traditional family supporter role is still strong, while men are also expected today to take part in child-rearing. The question is whether these processes effect on men's career.

This study presents career perspectives of male workers with or without child. The authors made a quantitative survey in order to get to know this question. Based on research conducted in 2016, it is possible to say that men with or without child are different in this question.

KEYWORDS: male workers with children or without children, career, work and private life reconciliation, gender role, conflict

\section{Bevezetés}

Napjainkban az egyik egyre inkább fontos menedzsment feladattá nőtte ki magát a munka és magánélet összehangolásának problematikája. A kérdés sokáig női kérdésként merült fel, mivel a klasszikus családmodellben a férfi volt a kereső, a nő feladata pedig a háztartás vezetésére és a gyermeknevelésre korlátozódott. Ezért a dolgozó nőknél jelentkezett elsősorban a munka és magánélet konfliktusa, mivel a családi gondok miatt romlott a munkahelyi teljesítményük. A nyolcvanas évek végén, a kilencvenes évek elején azonban egyre inkább azt lehetett tapasztalni, hogy ez a konfliktus nemcsak a nőket, hanem a férfiakat is érinti. Ennek egyik oka minden bizonnyal legalább részben az a tendencia, hogy a munka világába belépő nők száma világszerte növekszik. Például egy amerikai vizsgálat alapján az USA-ban 1970 és 2000 között a dolgozó nők száma szignifikáns növekedést mutatott (Blau - Ferber Winkler 2006).

A házas nők munkába állása miatt fokozódott a háztartásban és a gyermeknevelésben a férfiakra jutó otthoni feladatok száma és az e feladatok ellátására fordítandó idő. Mivel ezt az időt a férfiak vagy a munkahelyüktől veszik el, vagy a pihenéssel tölthető időből, ennek a következménye a fáradtság és a csökkenő munkahelyi teljesítmény lesz. Ez a férfiaknál is hasonló konfliktusok forrása lehet, mint a nők esetében. A szociális elvárásoknak megfelelni kívánó, hagyományos szerepkört megvalósító férfiak konfliktusa azonban elsősorban abból adódik, hogy a munkahelyi teljesítmény érdekében a családtól és a háztartási munkától veszik el az időt, ami otthoni vitákhoz, problémákhoz, esetleg váláshoz is vezethet. Igaz, ezeket a konfliktusokat a férfi munkavállalóknál nehezebb azonosítani, miután ők nem szívesen beszélnek az ilyen típusú problémájukról (Juhász 2014).

Természetesen felvetődik, hogy ez a kérdéskör mennyire intenzíven jelenik meg a férfiak életében különösen, ha a karrierjüket vizsgáljuk. Ennek hátterét elemzi a jelen tanulmány. 


\section{TEMATIKUS TANULMÁNYOK - Menedzsment: vezetők, vezetés és munkavállalók}

A továbblépés előtt a szerzők szükségét érzik, hogy tisztázzák azokat a fogalmakat, amelyekkel kapcsolatban már jelen munka címe is kérdéseket vet(het) fel. A magyar nyelvben használatos „családos”, „gyermekkel rendelkező”, „gyermekes” kifejezések több jelentésárnyalatot is hordoznak. Vizsgálatunk alanyait az alapján csoportosítottuk, hogy házasságban - vagy a jelen vizsgálat szempontjából általunk ezzel egyenértékűnek tekintett élettársi kapcsolatban - élnek-e, és van-e gyermekük vagy sem. Arra a férfira, aki házas és vele, valamint feleségével/élettársával egy családban élő gyermeke is van, a jelen tanulmányban, a továbbiakban a gyermekkel rendelkező vagy a gyermekes férfi kifejezést használjuk. A többi férfit gyermekkel nem rendelkező vagy nem gyermekes férfinak tekintjük.

Kérdésünk, hogy a gyermekes férfiak esetében ez a tény a pályafutásukkal kapcsolatos elképzeléseikre hatással van-e? Különösen azért, mert a nőkkel végzett vizsgálatok hivatkoznak arra, hogy a gyermek igenis befolyásoló tényezőként hathat a karrierdöntésekre (Juhász 2012, KSH 2011). Létezik-e ilyen jelenség a férfiaknál is? Ezekre a kérdésekre keresi a tanulmány a választ egy 2016-ban végzett saját vizsgálat alapján. Mielőtt azonban erre rátérnénk, tekintsük át a témára vonatkozó szakirodalmat a teljesség igénye nélkül!

\section{A munka és magánélet konfliktusára vonatkozó szakirodalom rövid áttekintése}

A munka és magánélet összeegyeztetésének kérdésköre a nők tömeges munkaerőpiaci megjelenésével került a menedzsment vizsgálatok fókuszába. Az összehangolás problematikája rámutatott arra, hogy ma már nem feltétlenül csak a bérezéssel lehet ösztönözni a munkavállalókat. A karrier és a magánélet közötti kölcsönhatással kapcsolatban számos tudományos teória született.

Friedman és Greenhaus (2000) elmélete szerint a munka és a magánélet reciprok módon függ össze: a munkahelyi problémák a magánéletre gyakorolnak negatív hatást, a magánéleti gondok viszont a munkateljesítményt befolyásolják hátrányosan, tehát egy kétarcú jelenségről beszélhetünk.

Clark (2000) határ-teória elve szerint a munkavállalók mindegyikének két életszférája van (otthoni és munkahelyi), melyek között nap, mint nap ingázik.

1999-ben látott napvilágot Edwards és Rothbard erőforrás megosztási elmélete. Ez a feltételezés az erőforrások felhasználására összpontosít: az egyén megosztja idejét, figyelmét, energiáit a magánélet és a munkahely között. Fontos, bár ritkábban említett erőforrás, a hatalom (döntéshozó szerep) is.

A szakirodalom kvalitatív áttekintő elemzései (Eby 2005, Korabik 2008) alapján nem egyértelmű a nemek közötti különbség mértéke a munka és magánélet közötti konfliktust tekintve, de jelentősnek tűnik. 


\section{TEMATIKUS TANULMÁNYOK - Menedzsment: vezetők, vezetés és munkavállalók}

Byron 2005-ös metaanalízisének eredménye alapján viszont a férfiak és a nők megkérdezéses vizsgálatában a válaszadók között nem volt jelentős a különbség. A képet részben árnyalja a kétkeresős család, a szülői szerep és a konfliktus jellege (időhiány, feszültség, vagy viselkedés miatt) valamint az a tény, hogy ha csökkentjük a megkérdezettek között az azonos munkát végzők számát.

Ollier-Malaterre és Foucreault 2017-es megállapítása szerint a család-munka interakciók az egyén szélesebb kulturális, intézményi és gazdasági környezetébe ágyazottak. A régebbi elméletek gyakori feltevése, hogy a férfiaknak és a nőknek a munka és magánélet összehangolásához köthető konfliktushoz való viszonya közötti eltérés a hagyományos férfi és női identitáson és szerepeken alapul.

Más tanulmányok (Fahlén 2014) megállapítása szerint viszont azokban a kultúrákban, ahol közösen megosztják a párok a háztartási teendőket, sokkal kisebb a nemek közötti különbség.

Duxbury, Higgins és Lee $(1991,1994)$ szerint a hagyományos nemi szerepek nagyban befolyásolják az egyéni érzékenységet a környezeti hatásokra. A munkára nagyobb hangsúlyt fektető férfiaknál a munkahelyi problémákra való fokozottabb érzékenység miatt könnyebben alakulnak ki a munkahelyi okokra visszavezethető családi problémák. A nők ugyanakkor érzékenyebben reagálnak az otthoni problémákra és ez többnyire a munkateljesítményükön is meglátszik. Ezt a hatást fokozza az önazonosság-szemlélet is, ami a hagyományos női-férfi mintákból ered.

A nők részvétele a bevételek biztosításában szinte minden családban megfigyelhető lett. Ez a jelentős változás az 1970-2000 közötti időszakban zajlott le. Az említett időszakot vizsgáló amerikai tanulmány megállapításai alapján az 1970-es években az amerikai családok zöme egykeresős volt. (Blau - Ferber - Winkler 2006) 2000-re viszont a megkérdezett családok több mint fele kétkeresős lett, ahol a párok egyformán keresnek, vagy a nő keres jobban.

Lachance-Grzela és Bouchard (2010) vizsgálatai azt mutatják, hogy a férfiak és a nők különbözőképpen élik meg munkahelyi és otthoni szerepeiket. Részben az az oka ennek, hogy a férfiak munkavégzése zömmel munkaerőpiaci, fizetésért végzett munka, míg a nőknél sokkal nagyobb szerepet játszik a háztartás vezetése. Amennyiben a nő munkát vállal, csak úgy tartható fenn a család, ha a férfi nagyobb mértékben vesz részt a házimunkában. Mintegy kompromisszumként nagyon sok nő dolgozik részmunkaidőben, hogy a karrierje is haladjon és eközben a családját is elláthassa. Férfiaknál ugyanakkor a részmunkaidős állások és egyéb alternatívák (pl. távmunka) nem jellemzőek. A család gazdasági struktúrájának jelentőségét az adja, hogy ez az átmenet és a kapcsolat a munkahelyi és az otthoni életszíntér között.

Míg a női munkavállalás népszerű, széles körben kutatott téma, a férfiak részvételét a háztartásban jóval kevesebben vizsgálják (Behson 2015). Ezek az újabb elemzések megállapítják, hogy az apák szülői szerepéhez szorosan kapcsolódik a közreműködés a gyermeknevelés mindennapi feladataiban. 


\section{TEMATIKUS TANULMÁNYOK - Menedzsment: vezetők, vezetés és munkavállalók}

Diekman és Eagly (2000) számos vizsgálat alapján mutatta ki a hagyományos nemi szerepek erózióját. A munkába álló nők viselkedésében gyakran megfigyelhető a férfi magatartásformák (határozottság, agresszivitás, versenyhajlam, teljesítménykényszer) felé konvergálás, másképpen megfogalmazva a maszkulinizáció. Ezt jól magyarázza a „doing-gender” elmélet, amely szerint a férfias vagy a nőies viselkedés a környezet által támasztott elvárásokhoz igazodik. Ráadásul a dolgozó nők nem is érzékelik, hogy magatartásuk már eltér a hagyományos nemi szerepektől.

A munkahelyi elégedettség nemcsak a magánéletre hat kedvezően, hanem fontos tényezője a vállalati versenyképességnek is. Mégis a munkáltatók meglehetősen merevek a reformokat illetően, pedig a fiatal generáció már egyértelműen kinyilvánította igényét, hogy családjával több időt szeretne tölteni. A 2017-es Modern Families Index kérdőív adatai már jól igazolják azt a tényt, hogy a fiatal apák és anyák (az úgynevezett millenniumi szülők) munkához és családhoz való viszonya alapjaiban más, mint az idősebb generáció tagjaié. Így például a fiatal szülők - közülük is elsősorban az apák - jóval nagyobb számban hajlandóak lennének kisebb fizetésért is dolgozni, azért, hogy többet lehessenek a családjukkal. (Working Families 2017)

\section{A kutatás módszertana}

A szerzők 2016-ban, vizsgálatot végeztek annak megismerése céljából, hogy a férfiak miképpen vélekednek saját karrier elképzeléseikről, azt milyen tényezők (pl. házasság, gyermek) befolyásolják akár pozitívan, akár negatívan. A válaszadóknak egy internetes kérdőívet kellett kitölteniük teljesen anonim módon, önkéntesen. A mintagyűjtés módszere a hólabda eljárás volt, ami alapján a vizsgálat nem tekinthető reprezentatívnak. Összesen 191 válaszadó vett részt a kutatásban.

A kérdőív több kérdéscsoport mentén járta körül a témát. Az első kérdéscsoport a minta specifikációját foglalta magában, azaz a válaszadók életkorát, lakóhelyét, családi állapotát, beosztását térképezte fel. A második kérdéskör a munkára és a családra vonatkozó elfoglaltságokat mérte fel, a harmadik terület a karrier szerepét vizsgálta a válaszadók életében, míg a negyedik a női és a férfi karrier megítélését.

A kérdőív jellemzően zárt kérdésekből épült fel, amelyek metrikus és nominális változókból álltak. A kiértékelés módja az egy- és többváltozós statisztikai módszerek alkalmazása volt: gyakorisági-, átlag-, szóráselemzések, khi-négyzet próba, nonparametrikus vizsgálatok.

Jelen tanulmány a következő kérdéseket vizsgálja meg:

- Alapvetően különböznek-e a gyermekkel rendelkező és a gyermekkel nem rendelkező férfiak karrier elképzelései?

- Van-e összefüggés a férfiak által a munkahelyen töltött idő és aközött, hogy van-e velük egy családban élő gyermek vagy sem? 


\section{TEMATIKUS TANULMÁNYOK - Menedzsment: vezetők, vezetés és munkavállalók}

- Van-e összefüggés a férfiak által a háztartási /gyermeknevelési feladatokkal töltött idő és aközött, hogy van-e velük egy családban élő gyermek vagy sem?

\section{A kutatási eredmények}

\section{A MINTA SPECIFIKÁCIÓJA}

A kérdőívre 191 válasz érkezett, mind férfi válaszadóktól.

Amennyiben a résztvevők életkorát vizsgáljuk elmondható, hogy legnagyobb arányban a 41 és 50 éves kor közöttiek válaszoltak (32,5\%). Hasonlóan nagy számban érkezett kérdőív a 21 és 30 éves korcsoportba tartozóktól is (26,7\%).

A megkérdezettek igen nagy arányban éltek a közép-magyarországi régióban (143 fő, azaz 74,9\%). Kis számban minden további régióból érkezett kérdőív.

A válaszadó férfiak közül 95 budapesti volt, megyeszékhelyen és egyéb városban élt 74 fö, a többiek községben laktak.

Legnagyobb arányban érettségivel rendelkeztek $(53,4 \%)$, de sokuknak volt felsőfokú végzettsége is $(31,4 \%)$.

A megkérdezettek közül 136 fő házas vagy kapcsolatban élt, 39 fő nőtlen volt, míg 10 fő elvált, a többiek egyedülállóak.

Amennyiben a gyermekek számát vizsgáljuk, akkor elmondható, hogy sokuknak nincs gyermeke (42,4\%), két gyermeket nevelt a megkérdezettek 26,7\%-a, egy gyermeket a 18,8\%-a, a többieknek három vagy több gyermeke volt, azaz a gyermekes férfiak aránya $57,6 \%$ volt.

A 191 megkérdezettből 95 volt beosztott, 24 fő felsővezető. A közép, illetve az alsó szintű vezetők száma 36, illetve 19 fő volt.

\section{A MUNKÁBAN TÖLTÖTT IDŐ}

A legtöbb férfi 8 és 10 óra közötti időt tölt munkahelyén $(53,4 \%)$, de sokan vannak olyanok is $(14,1 \%)$, akik 10 óránál is többet. A 8 óránál kevesebbet dolgozók aránya összesen $23 \%$ volt.

Azok a férfiak, akiknek gyermekük van, rendszerint több időt töltenek a munkahelyükön, mint akiknek nincs gyermekük. A 8 és 10 órát munkahelyükön töltők közül 64,7\% nevel gyermeket (66 fő), míg az ennél több időt munkahelyükön dolgozó férfiak közül 81,5\% gyermekes. A 4 óránál kevesebbet munkában töltött aktív férfiak 80\%-a gyermektelen (8 fó).

Ha azt vizsgáljuk, hogy a gyermekkel rendelkezők milyen arányban töltenek különböző időt a munkahelyükön, azt látjuk, hogy a legtöbben (60\%) 8-10 órát, míg a legkevesebben (1,8\%) 4 óránál kevesebbet. Ezek az arányszámok a gyermekkel nem rendelkező férfiaknál rendre 44,4\%, illetve 9,9\%. (1. ábra) 
www. metszetek.unideb.hu

\section{TEMATIKUS TANULMÁNYOK - Menedzsment: vezetők, vezetés és munkavállalók}

1. ábra. A férfiak által a munkahelyen töltött órák (\%)

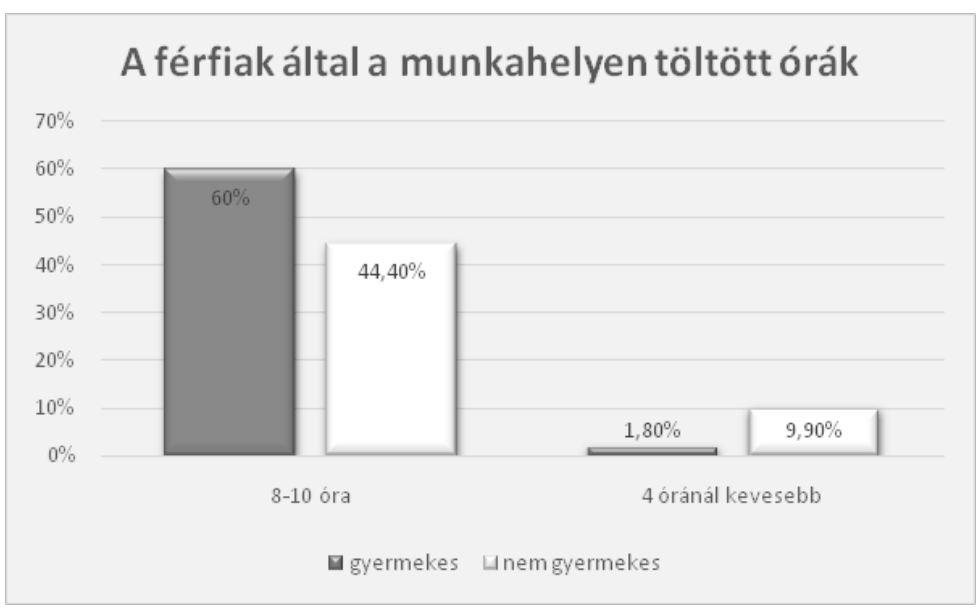

Forrás: Saját diagram

A szerzők megvizsgálták, hogy van-e kapcsolat aközött, hogy valakinek van-e gyermeke, és aközött, hogy mennyi időt tölt a munkahelyén. A Pearson-féle Khi-négyzet próba szignifikáns összefüggést mutatott ${ }^{4}$. Az ábra alapján az is megállapítható, hogy a gyermekkel rendelkező férfiak több időt töltenek a munkahelyükön, mint a gyermektelenek. Ez a tény első látásra meglepőnek tűnik, de egyben jelzi, hogy mennyire erősen hatnak a magyar férfiakra a hagyományos szociális elvárások (a férfi dolgozzon). Ezek az elvárások annyira erősek, hogy a munkahelyén kívül is dolgozó 100 férfi 66\%-a a gyermekes férfiak közül kerül ki. A Pearson-féle Khi-négyzet próba itt ugyan nem mutatott szignifikáns összefüggést a gyermekkel rendelkező és nem rendelkező férfiak, valamint a munkaidőn kívüli munkavégzés időtartama között, igaz, nem is volt megbízható a teszt. ${ }^{5}$ Ám maga a 66\%-os arány így is figyelemreméltó.

\section{A CSALÁDRA ÉS A HÁZTARTÁSRA FORDÍTOTT IDŐ}

Ugyancsak a hagyományos szerepminták hatásának erősségét jelzi a 2. ábra, ami a háztartással, a gyermekneveléssel töltött időt ábrázolja.

A legtöbb férfi kevesebb, mint két órát foglalkozott a háztartási teendőkkel függetlenül attól, hogy volt-e gyermeke. Ebben a kategóriában ugyan némileg maga-

\footnotetext{
${ }^{4}$ Pearson-féle Khi-négyzet: 30,432 df: 4 szign.: ,000 p <0,05.

${ }^{5}$ Pearson-féle Khi-négyzet: 9,47 df: 4 szign.: ,051 p>0,05.
} 


\section{TEMATIKUS TANULMÁNYOK - Menedzsment: vezetők, vezetés és munkavállalók}

sabb lett azok aránya, akiknek nincs családjuk. A két óránál kevesebb időt háztartási munkával töltők közül 46,5\% gyermekes, 53,5\% gyermektelen volt. Magasnak bizonyult továbbá még azok aránya is, akik 2-4 órában láttak el háztartási teendőket. Az összes gyermekkel rendelkező megkérdezett férfi 34,5\%-a tartozott ebbe a körbe, míg a gyermekkel nem rendelkezők közül ez az arány 19,8\% volt. Itt már eltolódott a megoszlás a gyermekes férfiak irányába, ugyanis 38 férfi töltött 2-4 órát háztartási munkával, míg itt a gyermekkel nem rendelkezők esetén ez a szám csak 16 fó volt.

2. ábra. A férfiak által a háztartásban töltött órák (\%)

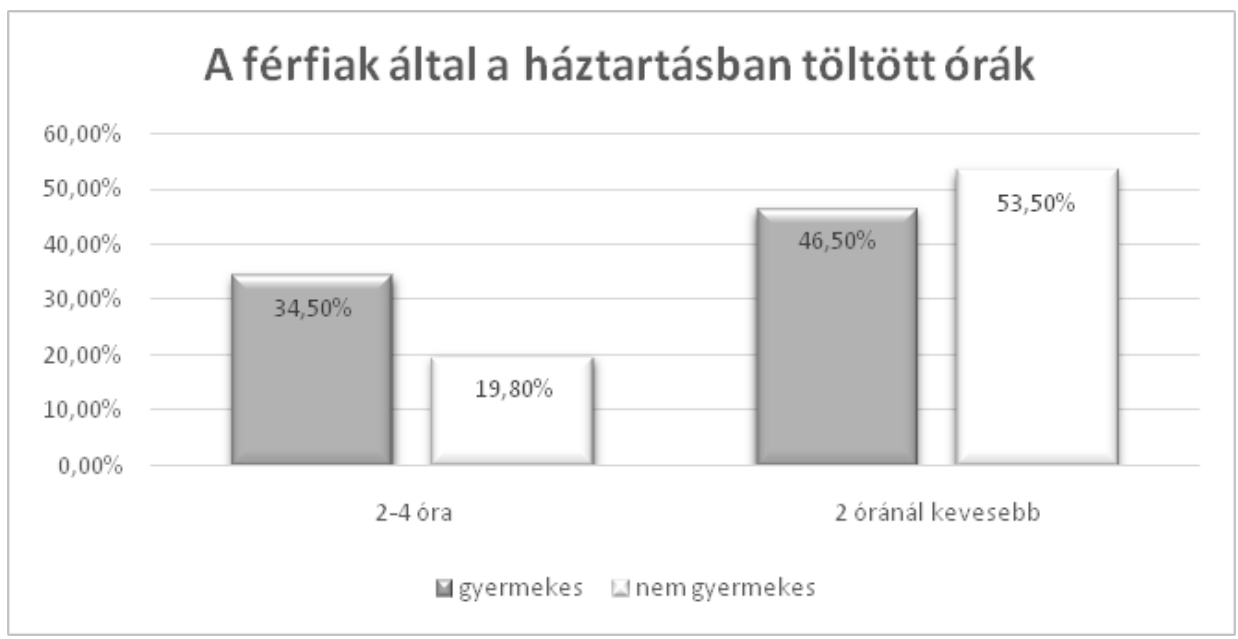

Forrás: Saját diagram

\section{A MUNKA ÉS A KARRIER KAPCSOLATÁNAK VIZSGÁLATA}

A szerzők rákérdeztek arra is, hogy a kutatásban résztvevők mennyire tudják összehangolni a munkájukat a karrierjükkel. Egy ötfokozatú Likert-skálán kellett értékelniük, hogy milyen mértékben képesek erre. Az egyes az egyáltalán nemet jelentette, míg az ötös a teljes mértékben válasznak felelt meg. A gyermekkel rendelkező férfiak általában össze tudták egyeztetni családi kötelezettségeiket a munkahelyi teendőkkel. Ezt a válaszok átlaga is mutatta, amely 3,85 lett.

A 110 gyermekes férfi közül 32 teljes mértékben, 40 pedig részben volt képes erre. Ezek a számok a nem gyermekes 81 férfi esetében a következőképpen alakultak: 24 fő tudta teljesen, illetve 26 fó részben összehangolni a munkáját a családi életével. 


\section{TEMATIKUS TANULMÁNYOK - Menedzsment: vezetők, vezetés és munkavállalók}

Amennyiben az egyes kategóriákat tekintjük azok között, akik teljes mértékben képesek összeegyeztetni otthoni teendőiket a munkával, 57,1\% gyermekes volt. Azoknál a válaszadóknál, akik csak részben tudták összeegyeztetni a feladatokat, a gyermekesek aránya 60,6\% lett. A kutatók elemezték azt, hogy-e kérdésben van-e szignifikáns különbség a gyermekes és a gyermektelen férfiak között. Miután az öszszeegyezetés megítélésére vonatkozó metrikus változó nem volt normál eloszlású, a különbségek megvizsgálására nonparametrikus vizsgálatot alkalmaztak a szerzők. A Mann-Whitney-teszt eredményeit az egyes táblázat mutatja:

1. táblázat. Mann-Whitney-teszt eredménye $(\mathrm{p}=0,05)$

\begin{tabular}{|l|c|}
\hline & $\begin{array}{c}\text { Mennyire tudja összeegyeztetni a munkahelyi } \\
\text { teendőit a családi kötelezettségekkel? }\end{array}$ \\
\hline Mann-Whitney U & 4358,5 \\
\hline Wilcoxon W & 7679,5 \\
\hline Z & $-0,268$ \\
\hline Asymp. Sig. (2-tailed) & 0,788 \\
\hline a Grouping Variable: gyermek & \\
\hline
\end{tabular}

Forrás: Saját táblázat

A táblázat adatai azt mutatják, hogy e tekintetben nem különböztek szignifikánsan a gyermekes és a nem gyermekes megkérdezettek.

A „Mennyire fontos az Ön számára a karrier?” kérdésre szintén egy ötfokozatú Likert-skálán kellett válaszolniuk a résztvevőknek. Az egyes az egyáltalán nem fontosat, az ötös a nagyon fontosat szimbolizálta. A válaszok 3,93-as átlagot mutattak, ami azt jelenti, hogy a vizsgálatban szereplő férfiak számára kardinális volt a szakmai pályafutás. Az összes válaszadó 39,8\%-ának volt nagyon fontos a karrierje (ez 76 főt jelentett), 31,4\%-uk (60 fő) ítélte részben jelentősnek. Összesen 22 fő válaszolta, hogy nem, vagy csak részben nem fontos a szakmai cél. Kérdés volt, hogy e tekintetben különböznek-e a gyermekes és a gyermekkel nem rendelkező válaszadók. A vizsgálat a metrikus változó nem normális eloszlása miatt megint nonparametrikus elemzés volt. Az eredményt a 2. táblázat foglalja össze: 
www. metszetek.unideb.hu

TEMATIKUS TANULMÁNYOK - Menedzsment: vezetők, vezetés és munkavállalók

2. táblázat. Mann-Whitney-teszt eredménye $(\mathrm{p}=0,05)$

\begin{tabular}{|l|c|}
\hline & $\begin{array}{c}\text { Mennyire fontos Önnek a személyes karrierje } \\
\text { a szakmájában? }\end{array}$ \\
\hline Mann-Whitney U & 3159,500 \\
\hline Wilcoxon W & 9264,500 \\
\hline Z & $-3,616$ \\
\hline Asymp. Sig. (2-tailed) &, 000 \\
\hline
\end{tabular}

Forrás: Saját táblázat

A táblázat azt mutatja, hogy a két csoport e kérdésben szignifikánsan különbözött egymástól. A gyermekkel rendelkező férfiak számára kevésbé volt fontos a karrier (átlag: 3,67), mint a nem gyermekeseknek (átlag: 4,27).

A szerzők azt is megvizsgálták, hogy a karrier fontosságát mennyire magyarázza az életkor illetve, hogy valakinek van-e gyermeke, avagy sem. Az F-próbával végzett elemzések azt mutatták, hogy a kor és a gyermek szignifikánsan hat a karrier fontosságára, igaz e két faktor, viszonylag kis mértékben magyarázta a karrier szerepét. ${ }^{6}$

A gyermekes férfiak 59,1\%-a gondolta úgy, hogy van számára karrierlehetőség a cégénél, ahol dolgozik, míg 39,1\%-uk szerint nem volt előrelépési perspektíva. A gyermekkel nem rendelkezők 40\%-a látott előrelépési lehetőséget, míg 25,9\%-uk szerint nem volt ilyen a cégnél.

A gyermeket nevelő férfiak 75,5\%-a úgy nyilatkozott, hogy a szakmájában van karrierlehetőség, 22,7\%-uk szerint nincs ilyen. Ha a gyermektelen férfiakat vizsgáljuk, akkor azok 75,3\%-a látott karrierlehetőséget szakmájában, míg 7,4\%-uk nem.

A gyermekkel rendelkező férfiak 39,1\%-ának (43 fő) mind a céges, mind a szakmai karrierje fontos volt. Elég magas volt azok aránya, akiknek a szakmai karrierje a legfontosabb (33,8\%, azaz 37 fő). Azok között, akik nem gyermekesek, ez az arány rendre 45,7\% -nak és 39,5\%-nak bizonyult.

A céges és a szakmai karriert egyaránt fontosnak ítélő válaszadók között a gyermekesek aránya 53,8\% volt, míg a kifejezetten a szakmai karriert előnyben részesítők között ugyanez a csoport 53,6\%-ban volt jelen. E kérdésben nem különböztek szignifikánsan a családos és a nem családos munkavállalók. ${ }^{7}$

A gyermekes apák 72,7\%-a gondolta úgy, hogy van számára karrierlehetőség a cégen kívül (ez 80 főt jelent). A gyermekkel nem rendelkezők közül 42\% látott kar-

\footnotetext{
${ }^{6} \mathrm{~F}$ próba: F: 3,597 szign.: ,004 p<0,05 R négyzet:, 089.

${ }^{7}$ Pearson-féle Khi-négyzet: 4,659 df: 4 szign.: ,199 p>0,05.
} 


\section{TEMATIKUS TANULMÁNYOK - Menedzsment: vezetők, vezetés és munkavállalók}

rierlehetőséget a munkahelyen túl (58 fő). E tekintetben szignifikánsan különbözött a két csoport egymástól. ${ }^{8}$

A gyermekes férfiak 51,8\%-a nyilatkozott úgy, hogy létezik karrier otthon is és a munkahelyen is, míg a gyermekkel nem rendelkezők 58\%-a gondolta ezt így. A gyermekkel rendelkezők közül sokan voltak olyanok is, akik szerint ez nem így van (33,6\%, azaz 37 fó). Együttesen 37 fónek nem volt ezzel kapcsolatos véleménye. A 104 válaszoló közül, aki szerint létezik karrier otthon és a munkahelyen egyaránt, 57 férfi volt gyermekes. 50-en mondták azt, hogy nincs karrierlehetőség a családon és a cégen belül, közülük nagyobb arányban voltak gyermekesek, számuk 37 fő.

Az összes megkérdezett közül a legtöbb esetben a feleség többet keresett a férjénél, 99-en válaszoltak így. 18 válaszadónál a férj és a feleség keresete azonos volt, míg 31 válaszadó esetében volt a férfi fizetése magasabb. A gyermekkel rendelkező férfiak 64,5\%-ának több volt a fizetése a párjáénál. A nem gyermekes férfiak 88,4\%a egyedülálló volt. E tekintetben szignifikánsan különbözött a gyermekes és a nem gyermekes válaszadók csoportja. ${ }^{9}$

\section{A NŐI ÉS A FÉRFI KARRIER MEGÍTÉLÉSE}

Egy következő kérdéscsoportban állításokat fogalmaztak meg a szerzők, amikről a válaszadóknak egy ötfokozatú Likert-skálán kellett eldönteniük, hogy mennyire értenek egyet az adott megállapítással. Az egyes az egyáltalán nem, az ötös a teljes mértékben megfelelője.

A férfiak 20,4\%-a értett egyet teljes mértékben azzal, hogy a férfiaknak karriert kell építeniük. Magas volt azok aránya is $(30,4 \%)$, akik inkább értettek egyet az állítással.

A férfiaknak csupán 4,2\%-a fogadta el, hogy a nőknek karriert kell építeniük. Legtöbben egyet is értettek, és nem is az állítással (40,8\%). A többiek hajlottak afelé, hogy a nőknek nem kell karriert befutniuk.

A válaszadók leginkább azzal nem tudtak azonosulni, hogy a szakmai karrier előbbre való a családinál. 77 fő ezzel egyáltalán nem (40,3\%), míg 57 fő inkább nem $(29,8 \%)$ értett egyet.

A legtöbb férfi úgy gondolta, hogy támogatnia kell párja szakmai karrierjét. Teljes mértékben helyesnek ítélte ezt meg 78 fő (40,8\%), míg inkább elfogadta 64 fő $(33,5 \%)$.

A válaszadók közül 117 fő (61,3\%) úgy nyilatkozott, hogy teljes mértékben támogatja a párja családi karrierjét. Inkább volt ezen az állásponton 27 fő (14,1\%). Mindössze 3 fő volt, aki inkább nem fogadta el ezt.

\footnotetext{
${ }^{8}$ Pearson-féle Khi-négyzet: 13,979 df: 2 szign.: ,001 p<0,05.

${ }^{9}$ Pearson-féle Khi-négyzet: 48,161 df: 3 szign.: ,000 p<0,05.
} 


\section{TEMATIKUS TANULMÁNYOK - Menedzsment: vezetők, vezetés és munkavállalók}

A férfiak általában megbeszélik a szakmai karrier lehetőségüket a párjukkal. Teljes mértékben így volt 66 főnél (34,6\%), inkább ez a gyakorlat élt 57 főnél (29,8\%), egyet is értett és nem is 46 fó ezzel a megoldással $(24,1 \%)$.

Kevés férfi volt, aki úgy vélekedett, hogy szakmai karrierjéről csak maga dönthet: 15 fő (7,9\%). A legtöbben nem tudtak azonosulni ezzel: 52 fő $(27,2 \%)$.

A férfiak úgy gondolták, hogy a nőknek a szakmai karrier lehetőségüket meg kell beszélniük párjukkal. Ezt teljes mértékben vallotta 68 fő (35,6\%), és inkább elfogadta 60 fö $(31,4 \%)$.

Kevesen voltak azon az állásponton, hogy a nő szakmai karrierjéről csak maga dönthet. Mindössze 11 férfi tudott azonosulni ezzel. 51 férfi nem utasította el az állítást, 48 válaszadó pedig inkább nem értett vele egyet.

A férfiak közül 88 fó egyáltalán nem fogadta el, hogy a szakmai karrierje fontosabb kell, hogy legyen, mint párja szakmai karrierje. 41 fő inkább nem értett egyet ezzel a megállapítással. 5 fő volt csupán, aki teljes mértékben osztotta ezt a véleményt.

A nők családi karrierje csak 5 fó esetében volt egyértelműen fontosabb, mint a párjáé. Elutasító volt ezzel az állítással 84 fő (44\%), míg 46 fő tudott valamilyen mértékben azonosulni vele $(24,1 \%)$.

Megoszlanak a vélemények azzal kapcsolatban, hogy a férfiak könnyebben építenek-e szakmai karriert, mint a nők. Teljes mértékben egyetértett ezzel 32 fő (16,8\%), inkább egyetértett 58 fő $(30,4 \%)$, egyet is értett és nem is 54 fő $(28,3 \%)$. A többiek hasonló arányban választottak a szélső lehetőségek közül.

A legtöbb férfi nem vallotta, hogy a férfiak fizetése magasabb ugyanabban a pozícióban, mint a nőké: 48 fő (25,1\%) számára ez elfogadhatatlan volt, 28-an (14,7\%) inkább nem értettek egyet vele. Azonban elég sokan voltak olyanok, akik részben jóváhagyták az állítást (46 fő, 24,1\%), míg teljes mértékben azonosulni tudott vele 26 fö $(13,6 \%)$.

Nem egyértelműek a válaszok abban a tekintetben, hogy a férfiak előbbre jutási lehetősége jobb-e a munkahelyen. Teljes mértékben támogatta ezt 26 fó, míg inkább azonosult vele 45 fő. Teljesen elutasította 39 fó, és inkább nem értett egyet ezzel 37 fö. A többiek egyet is értettek, és nem is az állítással.

A legtöbb férfi úgy gondolja, hogy egy nőnek támogatnia kell párja szakmai karrierjét. Ezt teljes mértékben helyesnek ítélte meg 75 fő (39,3\%), míg inkább egyetértett vele 55 fó $(28,8 \%)$.

A vizsgálat során elemzésre került, hogy a fenti esetekben van-e szignifikáns véleménykülönbség a gyermekkel rendelkező és a gyermek nélküliek között. A 3. táblázat azokat az eseteket tartalmazza, ahol igazolható volt a szignifikáns eltérés. 
www. metszetek.unideb.hu

\section{TEMATIKUS TANULMÁNYOK - Menedzsment: vezetők, vezetés és munkavállalók}

3. táblázat. Szignifikáns véleménykülönbségek $(\mathrm{p}=0,05)$

\begin{tabular}{|l|c|c|c|c|}
\hline & Mann-Whitney $U$ & Wilcoxon $W$ & $Z$ & $\begin{array}{c}\text { Asymp. Sig. } \\
\text { (2-tailed) }\end{array}$ \\
\hline $\begin{array}{l}\text { A férfiaknak kötelező karriert } \\
\text { építeniük. }\end{array}$ & 3562,000 & 9667,000 & $-2,436$ &, 015 \\
\hline $\begin{array}{l}\text { A nőknek kötelező karriert } \\
\text { építeniük. }\end{array}$ & 3375,000 & 9480,000 & $-2,995$ &, 003 \\
\hline $\begin{array}{l}\text { Számomra a szakmai karrier } \\
\text { előbbre való a családinál. }\end{array}$ & 3695,500 & 9800,500 & $-2,120$ &, 034 \\
\hline $\begin{array}{l}\text { Egy nő szakmai karrierjéről } \\
\text { csak maga dönthet. }\end{array}$ & 3504,000 & 9609,000 & $-2,594$ &, 009 \\
\hline
\end{tabular}

Forrás: Saját táblázat

A vizsgálatok azt is alátámasztották, hogy valamennyi állítás esetében a gyermekkel nem rendelkezők erőteljesebben tudtak azonosulni a fenti megállapításokkal.

\section{Összegzés}

A tanulmány egy 2016-os saját kutatás néhány eredményét foglalta össze. A vizsgálat többek között arra kereste a választ, hogy a gyermekkel rendelkező és a nem rendelkező férfiak között van-e különbség a tekintetben, ahogyan a szakmai életpályájukról és annak lehetőségeiről vélekednek. A fenti minta esetében azt tudják megállapítani a szerzők, hogy számos tényező esetében eltérően vélekednek erről a kérdésről a gyermekkel rendelkező és a nem rendelkező férfi munkavállalók.

A válaszok többnyire azt tükrözik, hogy a gyermekes férfiak számára a karrier szerepe nem olyan fontos, mint a gyermekkel nem rendelkezőknek. Ezzel összhangban van az az eredmény, ami szerint a gyermekes férfiak nagyobb arányban vállalnak részt a háztartási feladatokból, mint a gyermek nélküliek. Látszólag ellentmond az előbbi megállapításoknak az a vizsgálati eredmény, hogy a gyermekkel rendelkező férfiak több időt töltenek a munkahelyükön, mint a nem gyermekesek, de ennek magyarázata lehet az a tény, hogy nekik egy család eltartásáról kell gondoskodniuk.

Ez azt is mutatja, hogy a család, a férfiak esetében is, hatással lehet arra, hogy miképpen döntenek a karrier elképzeléseiket illetően. Az eredmények azt mutatják, hogy a férfiak többsége elismeri párja szakmai karrierrel kapcsolatos igényeit és hajlandó megbeszélni, illetve támogatni is azokat. 


\section{TEMATIKUS TANULMÁNYOK - Menedzsment: vezetők, vezetés és munkavállalók}

A szerzők tovább folytatva a kutatást azt fogják vizsgálni, hogy ez a determináló hatás melyik nemnél milyen erősségű, és mi befolyásolja annak intenzitását.

További vizsgálati terület lehet az ún. millenniumi generációs szülők vizsgálata, mivel a szakirodalom szerint (Working Families, 2017), ők már sokkal kedvezőbben viszonyulnak a fenti kérdésekhez, mint az idősebb korosztály. Márpedig a jövő munkahelyeinek nemcsak dolgozói, hanem vezetői is egyre inkább közülük fognak kikerülni, ami a versenyképességre is komoly hatással lehet.

\section{Irodalom}

Behson, S. J. (2015): The Working Dad's Survival Guide: How to Succeed at Work and at Home. Motivational Press

Bencsik A. - Juhász T. (2012): Men on Parental Leave in Hungary. In: R Ginevičius, A. V. - Rutkauskas, J. Stankevičienè (szerk.) Business and Management 2012: 7th International Scientific Conference. Konferencia helye, ideje: Vilnius, Litvánia, 2012.05.10-2012.05.11. Vilnius: Vilnius Gediminas Technical University Press, pp. 616-623.

Blau, F. D. - Ferber M. A. - Winkler, A. E. (2006): The Economics of Women, Men and Work. Saddle Back. NJ: Prentice Hall.

Byron, K. (2005): A Meta-Analytic Review of Work-Family Conflict and Its Antecedents. In: Journal of Vocational Behavior, 67. pp. 169-198.

Clark, S. C. (2000): Work/Family Border Theory: A New Theory of Work/Family Balance. In: Human Relations 53(6). pp. 747-770.

Diekman, A. B. - Eagly, A. H. (2000): Stereotypes as Dynamic Constructs: Women and Men of the Past, Present, and Future. In: Personality and Social Psychology Bulletin. 26. pp. 1171-1188.

Duxbury, L. E. - Higgins, C. A. (1991): Gender Differences in Work-Family Conflict. in: Journal of Applied Psychology. 76. pp. 60-74.

Duxbury, L. - Higgins, C.- Lee C. (1994): Work-Family Conflict: A Comparison by Gender, Family Type, and Perceived Control. In: Journal of Family Issues. 15. pp. 449-466.

Edwards, JR. - Rothbard NP. (1999): Work and Family Stress and Well-Being: An Examination of Person-Environment Fit in the Work and Family Domains. In: Organizational Behavior and Human Decision Processes 77(2). pp. 85-129.

Fahlén S. (2014): Does Gender Matter? Policies, Norms and the Gender Gap in Workto-Home and Home-to-Work Conflict Across Europe. In: Community, Work \& Family, 17. pp. 371-391. 
www. metszetek.unideb.hu

\section{TEMATIKUS TANULMÁNYOK - Menedzsment: vezetők, vezetés és munkavállalók}

Friedman, S. - Greenhaus, J. (2000): Work and Family - Allies or Enemies? What Happens When Business Professionals Confront Life Choices. New York: Oxford University Press

Juhász T. (2012): A nők visszatérési esélyei a munkaerőpiacra a gyermekgondozási szabadság után a közép-magyarországi régióban empirikus vizsgálat alapján. In: Gazdasági és Társadalomtudományi Közlemények. pp. 211-216.

Juhász T. (2014): Családbarát munkahelyek, családbarát szervezetek. Publikon Kiadó, Pécs

KSH (2011): Munkavégzés és családi kötöttségek. www.ksh.hu, pp. 1-41.

Lachance-Grzela, M. - Bouchard, G. (2010): Why Do Women Do the Lion's Share of Housework? In: A Decade of Research. Sex Role. doi:10.1007/s11199-0109797-z

Ollier-Malaterre, A. - Foucreault, A. (2017): Cross-National Work-Life Research: Cultural and Structural Impacts for Individuals and Organizations. In: Journal of Management, 43, pp. 111-136.

Working Families and Bright Horizons: The Modern Families Index 2017. https:// www.workingfamilies.org.uk/wp-content/uploads/2017/01/Modern-Families-Index_Full-Report-1.pdf 